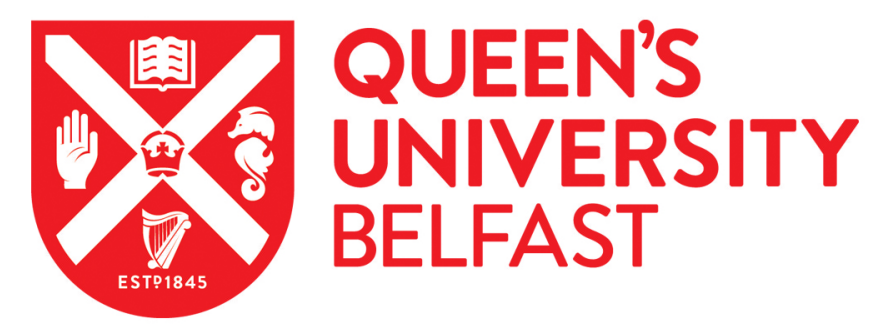

\title{
The influence of institutional factors on corporate narratives: a thematic content analysis of Guinness
}

Moreno, A., \& Quinn, M. (2020). The influence of institutional factors on corporate narratives: a thematic content analysis of Guinness. Accounting History, 25(3), 425-447. https://doi.org/10.1177/1032373219881811

Published in:
Accounting History

Document Version:

Peer reviewed version

Queen's University Belfast - Research Portal:

Link to publication record in Queen's University Belfast Research Portal

Publisher rights

( 2019 The Authors. This work is made available online in accordance with the publisher's policies. Please refer to any applicable terms of use of the publisher.

\section{General rights}

Copyright for the publications made accessible via the Queen's University Belfast Research Portal is retained by the author(s) and / or other copyright owners and it is a condition of accessing these publications that users recognise and abide by the legal requirements associated with these rights.

Take down policy

The Research Portal is Queen's institutional repository that provides access to Queen's research output. Every effort has been made to ensure that content in the Research Portal does not infringe any person's rights, or applicable UK laws. If you discover content in the Research Portal that you believe breaches copyright or violates any law, please contact openaccess@qub.ac.uk. 


\title{
The influence of institutional factors on corporate narratives: a thematic content analysis of Guinness
}

\begin{abstract}
This paper provides a thematic content analysis of the Chairman's Statement of Arthur Guinness \& Son Ltd over time. The analysis traces the evolution of the content over four distinct periods using a coding scheme developed from extant research. The objective is to study whether the corporate narratives change in line with the institutional factors over time. To interpret the results, we draw on an institutional theory-based lens to offer potential explanations of some of the change and stability noted. Institutions can constrain behaviour, but they can also support and empower agents to bring about change. The results of the longitudinal content analysis reveals some variations over time, but in general the content is relatively stable. This may be explained by the organisation itself being an institution that is sufficiently institutionalised so that corporate reporting remained relatively stable. This suggests Guinness may be an example of a strong institution over time.
\end{abstract}

\section{Keywords}

Thematic content analysis, disclosure, Guinness, institutional factors. 


\section{Introduction}

Accounting can only be understood in its social and institutional context (Miller, 1994) and the general business and economic environment, which comprises various institutional pressures, can influence organisations in general, and corporate information in particular (Scott, 2014). The role of institutions in accounting change has been previously addressed (Burns and Scapens, 2000; Ribeiro and Scapens, 2006). In the case of external reporting practices, Suddaby et al. (2009) suggest this relationship can be tested by conducting content analysis of corporate texts, such as annual reports. However, the institutional impact in the disclosure has not commonly analysed over long periods of time. Longitudinal studies are an appropriate research method to test influences of institutional forces (Burns, 2000) and they reveal patterns of corporate reporting over time (Baskerville et al., 2014; Campbell and Abdul Rahman, 2010).

The objective of this study is to analyse and interpret patterns of change and/or stability in historical externally focused corporate information, and contrast this to varying levels of institutional pressures over time using a thematic content analysis of discretional corporate narratives. To do this, after a statistical analysis of content, some elements of institutional theory (mainly drawing on Scott, 2014) are adopted as a lens to offer potential interpretations for changing patterns in the corporate information. Specifically, behind an identification of the different phases in the institutional environment, associated with different economic and social characteristics, we analyse 
the potential impact of institutional forces on the themes covered by the Chairman's Statement over time (Langton and West, 2016; Moreno and Cámara, 2014). This type of study can be used to not only reveal general insights, trends and changes of the factors affecting firms, but also provide a basis for comparative analysis between firms.

Narrative information part of annual reports has been subject to content analysis by previous literature (Jones and Shoemaker, 1994); however, studies over long consecutive periods of history are uncommon (Guthrie and Parker, 1989; Neimark and Tinker, 1986). Longitudinal studies are suitable to study changes over time (Dawson, 2003), but they require the collection of data over long periods of time. In terms of longer periods in history, the corporate archives of Arthur Guinness \& Son Ltd (hereafter Guinness) has extensive holdings. Guinness also offers unique conditions in the sense that it was always a profitable company from its incorporation in 1886 . It could involve specific institutional circumstances not properly addressed by previous research. For these reasons, and because it is a well-known multinational company, we analyse the historical corporate information disclosed by Guinness. The archival holdings of Guinness have been subject to some prior studies. For example, studies by Quinn (2014) and Quinn and Jackson (2014) focus on internal (management), and another by Hiebl et al. (2015) focuses on roles of accounting staff. They focus on more technical business aspects and are more related to management accounting. In addition, there are other studies focused on the Guinness disclosure. Cleary et al. (2018) examine a short period 
of the Chairman's Statement, using a family business approach, to analyse the socioemotional wealth of the narratives in comparison with another Irish brewery, Murphy's. Moreno et al. (2019) also analyse the Chairman's Statement over time. They, using an analysis software method, focus on the form of the message to analyse if the company managed some textual characteristics in line with impression management. In contrast, the present paper, under a manual content analysis, focuses on the substance of the message to analyse if the company adapts themes covered by its disclosure along with the different institutionalised environments which it went through.

One of the most important documents which is typically part of the annual report is the Chairman's Statement. It is one of the primary documents used to communicate accounting and other data to stakeholders in the past and present (Courtis, 1998) and it is one of the most widely read elements of the annual report (Abrahamson and Park, 1994). Its non-standard character allows companies discretion to decide the content disclosed. It provides a summary of operations, strategies, accounting results and the general state of the business (Balata and Breton, 2005). Such information provides a basis for comparison with previous and future research.

The remainder of the paper is structured as follows. The next section provides the theoretical framework, which draws on what may be generally termed a neoinstitutionalist approach. A brief history of Guinness, the brewing sector and economic/social conditions during our analysis period is then given. This is followed by 
an explanation of our method, a thematic content analysis, which we place in the context of similar prior studies. Our findings are then detailed, offering some statistical analysis to identify similarities and differences of the themes within the Chairman's Statement over time. This is followed by an exploration of the similarities and differences from an institutional perspective.

\section{Theoretical framework}

We are adopting a neo-institutionalist history approach, as noted by Rowlinson and Hassard (2013), to interpret our findings. That is, we use institutional theory as a lens to interpret historical facts. Such an institutional approach has been utilised previously in accounting history research (Fowler and Keeper, 2016), including the influence on management accounting (Carmona and Macías, 2001), accounting rules (Caria and Rodrigues, 2014), disclosure (Langton and West, 2016), costing methods (Gervais and Quinn, 2016) or accounting change (Quinn, 2014; Quinn and Jackson, 2014; Spraakman, 2006). Institutional theory, in its various forms, has been more widely used in the contemporary literature to study various aspects of accounting change (see for example, Burns and Scapens, 2000; Ribeiro and Scapens, 2006; Sharma et al., 2014; Tsamenyi et al., 2006). However, as noted by scholars such as Moll et al. (2006), Wanderly et al. (2011) and van der Steen (2006), the various standalone branches of institutional theory alone are subject to some criticisms. This implies they are sometimes drawn upon in part 
- with concepts used in a standalone fashion - or combined with other theoretical framings to explain phenomena, depending on the research context. This approach permeates both the contemporary and historic accounting literature. To give two brief examples, from the accounting history literature, Moreno and Cámara (2014) draw on the nature of the institutional environment and analyse how it affects corporate disclosures; or, from the contemporary literature, Colasse and Pochet (2009) draw on coercive and mimetic isomorphism to explore the accounting standards setting process.

To begin, a definition of institutions is useful. Scott (2014: 56) defines institutions as 'composed of cultural-cognitive, normative, and regulative elements that, together with associated activities and resources, provide stability and meaning to social life'. According to Scott, there are differing schools of thought as to relationship between institutions and organisations (Scott, 2014). North (1990) for example, regards institutions as the rules of the game, organisations as players. Other writers such as Selznick (1957) and Williamson (1985) view organisations as distinct institutions which take into account choices of agents within the organisation. Others still, such as Meyer and Rowan (1977) stress the connection between society and individual organisations, suggesting that if the latter are deemed institutions, they take elements from the societal level. Regardless of what view we take, organisations are either institutions in their own right, or interact with institutions at a more macro level. For the purpose of this paper, we view organisations as both institutions and as being influenced by other institutions - such 
as other organisations in the same field ${ }^{1}$ or government, for example. This view is supported by Scott (2014), as he differentiates between levels of institutions, ranging from world system ${ }^{2}$ level, through society, organisational field, organisational population, organisation and to organisational subsystems. Each of these six levels are regarded as open and 'are porous in the sense that activities and meanings occurring on one level are often linked to and activate activities and meanings at other levels' (Scott, 2014: 105).

As Scott (2014) notes, institutions can constrain behaviour, but they can also support and empower agents to bring about change. He also notes the elements of institutions as being some or all of regulative, normative and cultural-cognitive systems. Table 1 summarises key elements of these three pillars of institutions. Briefly, the regulative pillar is underscored in most institutionalist work as institutions constrain behaviour. This pillar emphasises rule setting and sanctioning power by regulators, governments and the legal system. However, if regulatory rules are weak, organisations may challenge them and gain power. The normative pillar refers to norms and values which set out how things should be done. For example, professional accounting bodies may be a normative force on accounting in organisations. Finally, the cultural-cognitive pillar focuses on shared meanings of social reality. Thus, the human agent is an important element of this pillar, interpreting external cultural frameworks (Scott, 2014). The three pillars of institutions support the varying levels also described by Scott (2014). For 
example, the world system is likely to be more regulative in nature, organisational field more normative in nature and society more cultural-cognitive in nature.

\section{[Insert Table 1 around here]}

In terms of our analysis of Guinness, we would expect one or more of the three pillars set out in Table 1 to influence the organisation (as an institution) over time, with this influence stemming from various institutional levels. Similarly, over time, it is possible for an organisation to influence higher levels, such as the organisational field, or even society. To give some examples, it may be that at points in time new legislation - the regulative pillar, at the world system level - may have a greater influence; at other times the normative effect of the brewing sector (organisational field level) or society may be more influential - which are more associated with the normative and/or cultural-cognitive pillars. Given that as Scott (2014) depicts the various institutional levels as porous, organisational change brought about by interactions with/influences of other institutions should be apparent through outward looking documents within the annual report and accounts such as the Chairman's Statement. Of particular interest for this study is the mechanisms and indicators noted in Table 1 - coercive, normative and mimetic - and how various institutional levels may (or may not) have had influence on the organisation. DiMaggio and Powell (1991) use these same terms to describe three types of isomorphism, whereby organisations in the same field take on similar characteristics. 
As noted by Oliver (1992), longitudinal studies of institutionalised activities under changing conditions are particularly appropriate for examining the contextual factors which bring about the potential destabilisation of institutional practices - such as corporate reporting. In this respect, Meyer (1986) suggests that different contexts may determine the amount of information that a particular organisation produces and recent longitudinal research has found that context can induce changes in the content of the annual reports (Langton and West, 2016; Moreno and Cámara, 2014). Consequently, we would expect the content of the Chairman's Statement to change in line with the context. This, drawing of the preceding discussion also, leads us to our hypothesis:

H1: The content of the Chairman's Statement changes over time according to different institutional contexts experienced by the company.

However, as noted by many institutional works, change and stability go hand-inhand (see for example Burns and Scapens, 2000; Quinn, 2014). Thus, there is always a possibility that the organisation, as an institution, remains stable despite institutional forces for change (from other institutional levels) being at play. This stability may be due to the power of existing institutional factors, being so taken-for-granted and embedded that organisations can remain relatively unaffected and stable. Of course, exploring the more micro-level institutional practices within organisations is typically not part of newinstitutionalist based work like that of Scott (2014). Similarly, we do not detail or interpret the inner workings of Guinness, but we do acknowledge that institutions are complex 
phenomena which span micro and macro levels of society (Dillard et al., 2004; Scott, 2014).

\section{Context - organisational, industrial and socio-economic}

To set the context for the remainder of this paper, we provide an overview of several factors, which we draw upon later using our institutional lens. First, a brief history of Guinness is provided, together with an overview of the brewing sector in Ireland/UK during our period of analysis. Apart from secondary sources, the history of Guinness is supplemented with material from their corporate archives and the annual reports. Then, we summarise the economic and social environment of Ireland and the UK.

\section{Guinness and the brewing sector}

In 1759, Arthur Guinness signed a 9,000-year lease on the St. James's Gate Brewery site in Dublin, Ireland. The site contained a brewery that was small and poorly equipped. In the early years, most trade was within Dublin, but from 1801 to 1850 trade increased tenfold. This increased trade was primarily due to the English market, represented about $60 \%$ in value terms. After 1850, Irish trade outside Dublin was the primary growth area. Revenues in the 1870's were on average $£ 1$ million annually (Lynch and Vaizey, 1960). The business was incorporated in 1886, and the Board of Directors of the new company (Arthur Guinness \& Son Ltd) consisted of mainly Guinness family members. Sir Edward Guinness was the first Chairman of the company. The first annual report of the company 
from 1887 shows a profit before tax of $£ 544,985$. The company expanded its 'Foreign Trade' by local bottling in the pursuing years, making sales to places such as South Africa, Canada, Australia, the United States and the West Indies (Dennison and MacDonagh, 1998). By 1920, profits before tax and dividends were $£ 3.26$ million. In 1936, a brewery was opened in London, at Park Royal. At this time, annual profits had declined somewhat to $£ 1.83$ million. After World War II, reported profits rose reaching $£ 4.6$ million in 1950 , and $£ 8.2$ million in 1960 . The late 1950 s and into the 1970 s was an expansionary period for the company, through acquisition, investment and licensing/contract arrangements. For example, in 1963 a brewery was opened in Nigeria, in 1965 in Malaysia, and in 1970 in Cameroon. By 1980, profits had risen to $£ 49.5$ million, of which $£ 40$ million was attributed to the Irish and UK markets. Turnover was almost $£ 800$ million. Ten years later in 1990 , turnover was in excess of $£ 3.5$ billion and profits stood at $£ 847$ million. This large increase is due primarily to the acquisition of Distillers Company Ltd in 1986, bringing many famous whiskey brands under the Guinness umbrella. The turnover from the distilling operations was $£ 2.1$ billion of the $£ 3.5$ billion total in 1990 . The 1996 annual report notes 'the highest ever pre-tax profit' of $£ 975$ million, on a turnover of $£ 4.73$ billion. This same year also saw the end of the Guinness company, as it merged with Grand Metropolitan to form a new entity Diageo plc. The 2016 annual report of Diageo shows a global turnover of $£ 15.6$ billion, and the group is one of the world's largest drinks groups. It is also worth noting that, from the company's incorporation in 1886 , the 
Guinness family made up a large majority of the Board of Directors and were also substantial shareholders. Our reading of the annual reports from 1948 to 1996 in additional shows that a member of the Guinness family remained as Chairman until 1985.

In terms of the brewing sector, Higgins et al. (2016) define the British beer industry as historically vertically tied. In 1900, there were 308 incorporated breweries with securities traded on a stock market. These had a total paid-up capital of over $£ 165$ million (Acheson et al., 2016). Coming closer to our analysis period (1948 to 1996, see later), the number of breweries declined after World War II, with Gourvish and Wilson (1994: 447) describing the period from 1955 to 1980 as 'merger mania'³. They also note the effects of brewing technology advances. On mergers, the number of brewing companies fell from 305 in 1954 to 81 by 1980 . The vast majority of mergers/acquisitions were from 1959-1961 and by 1967, seven companies controlled 73 per cent of the market. There were two main reasons behind merger activity at this time according to Gourvish and Wilson (1994). The first reason was the general growth in the global economy, leading companies to obtain more finance, increase markets and seek economies of scale. A second reason was more brewing specific, mainly the increasing demand for alcoholic drinks in general. For example, the number of licensed premises in the UK increased from 128,500 to 199,500 from 1951 to 1989 (Gourvish and Wilson, 1994). Guinness was less involved in the merger mania than what eventually became the $\mathrm{Big} \mathrm{Six}^{4}$, but did acquire some breweries in Ireland in particular during this time. For example, Guinness acquired 
the Smithwicks Brewery in 1964 (Irish Times, 1964) and Cairnes Brewery in 1959 (Irish Times, 1959). Of course, Guinness itself was part of a later merger, with Grand Metropolitan in 1996. On technology advances in the sector, as Gourvish and Wilson (1994: 534) note 'research had a low profile until cost accountants began to quantify the savings achieved" ${ }^{2}$. The developments in technology included production and brewing advances, and they generated large savings for the industry.

\section{The economy and society}

We now provide a summary of the Irish and UK economic and social conditions during our analysis period - 1948 to 1996. Although Guinness was incorporated when Ireland was part of the UK, its largest brewing site for many years was the St. James's Gate Brewery in Dublin. While Guinness did trade outside of Ireland, the company considered Ireland and the UK as the 'Home' market. For example, its 1970 annual report states the home market as contributing $72 \%$ of profit; this was $79 \%$ in the 1980 annual report $(40 \%$ to the UK, $39 \%$ to Ireland). The economies of the two countries by-and-large were in similar economic cycles during our analysis period (see below), and the Irish Punt was pegged to the Pound Sterling until 1979. A summary of activity from an economic perspective is given first, starting with Ireland - we should note Ireland refers to the Republic of Ireland unless stated otherwise.

O'Gráda (1997) provides a useful summary of the Irish economy during our analysis period ${ }^{6}$. While the Second World War (or The Emergency as it was officially 
termed in neutral Ireland) affected the economy with exports, wages and investment all falling, the post war years saw a great increase in consumption, public expenditure (particularly on social housing) and industrial output. The period from 1950 to 1959 was a period of 'gloom and doom' according to O'Gráda (1997). Rising imports resulted in a balance of payment crisis, which was not helped by a devaluation of the pound sterling in 1948 and the Korean War in 1950. The Irish government adopted strict fiscal measures, imposing more direct/indirect taxes and import levies on high value goods. In 1958, a government initiated Programme for Economic Expansion is cited as one reason for a pick-up in the economy; other reasons include a return on earlier social investments and improved trading at the international level. O'Gráda (1997) terms 1959-1979 as 'Ireland's golden age'. During the 1960's the economy grew 'at an unprecedented rate'. Growth continued into the early 1970's, but in 1973 a new coalition government increased public expenditure at the same time as the oil crisis. Ireland also joined the European Economic Community (EEC) this same year. Its membership could be construed as the opening up of many new markets, and thus a potential opportunity for future business growth ${ }^{7}$. Government spending was cut back in 1975, but a new government in 1977 increased expenditure and cut taxes. National debt soon rose. This ultimately led to 'more gloom and doom' from 1979 to 1985 . Unemployment rose and tax increases/spending cuts were put in place in earnest in 1983 in an effort to reduce national debt. O'Gráda (1997) refers to the 1985 to 2000 period as 'the only way is up'. A continued strategy of getting public 
finances in order, large capital investments by multinational firms, increased labour force participation and increased demand for Irish exports all resulted in positive economic and business conditions. To summarise, the Irish economy had four distinct stages during our analysis period, and we now contrast these to the UK.

In terms of the UK economy, economic conditions were broadly similar. Morys (2014) provides a useful review of UK economic cycles from 1870 to 2010 . Following an initial gloomy stage after the Second World War, Morys (2014) suggests the period from 1950 to 1973 was once of primarily economic growth for the UK economy. As in the Irish economy, the UK government tried to influence the economy using growth policies (Morys, 2014: 248-249). The period 1973 to 2010 is classified as a mixed period by Morys (2014). The oil crisis shock was also felt in the UK, and the end of the 1970s and early 1980s seen 'quadrupling of unemployment number, as well as the most dramatic structural transformation of the UK economy since the Second World War' (Morys, 2014: 240). From about 1982 to 2007, a combination of privatisation of inefficient state enterprises, deregulation and responsible fiscal and monetary policies saw a period of strong economic growth. This period of growth is similar to 'the only way is up' period in Ireland as described by O'Gráda (1997). In summary, while the division of the period from 1948-1996 in economic terms as described here is not identical, the broad division is similar and we thus deem the Irish and UK economic conditions as similar for the 
purposes of this study. In addition, Bielenberg and Ryan (2012) have suggested the economic performance of Ireland and the UK were relatively similar from about 1960.

We now turn to societal conditions during our analysis period. To provide an extensive summary of societal conditions and change is beyond the scope of this paper, and many volumes have been written on Irish and UK society. We first summarise some key tenets of Irish society covering the period of our research. In demographic terms, the population of the island of Ireland increased from about 4.2 million in 1940 to about 5.1 million in 1990. Life expectancy increased from 58 years in 1941 to 77 years by 2001 (Fitzgerald, 2017). Ireland has consistently witnessed emigration over the years, and the 1950s, 1960s, 1970s and 1980s saw net emigration in the Republic of Ireland, with the 1990s and later having net immigration (mainly due to more EU workers entering Ireland (Fitzgerald, 2017). As the population grew, so too did class distribution and the key industry sectors in Ireland. As noted by Ruane and Todd (2017) for example, the period from 1960 to 2011 say the employment levels in agriculture fall from $37 \%$ to $5 \%$. They note more foreign direct investment (FDI) and joining the EU increased economic growth, and in turn better jobs and incomes. This is borne out by real average industrial wage statistics, which in 1948 stood at $€ 162$ per week, which rose to $€ 536$ by $1996^{8}$. This in turn created a larger middle class over time. This is confirmed by Adelman (2017) who details the changing food diet over the period 1945-1999. Adelman (2017) notes a government survey which highlights food deficiencies in the general Irish population in 
1947. A similar survey 50 years later in 1997 highlighted 'high rates of obesity, excessive alcohol consumption and nutrients linked to particular medical problems' (Adelman, 2017: 241). It is worth noting that in the second half of the twentieth century, the consumption of alcohol was also closely related to the development of the economy ${ }^{9}$.

Turning now to the UK society, we should first state that there is a political link between the two societies in the form of Northern Ireland. While we do not focus on political factors in this paper, violence in Northern Irish society affected both business and society in mainland UK and the Republic of Ireland to some degree from the late 1960s. For our summary of key tenets in UK society during the analysis period, we draw on Royle (2012) and we summarise the same tenets in general as those described for Ireland above. Similar to Ireland, the UK population increased during our analysis period - for example the population of England and Wales increased from 43.8 million in 1951 to 52.4 million by 2001 . The corresponding figures for Scotland remained relatively stable at 5.1 million (Royle, 2012: 37). However, unlike Ireland with one major urban centre (Dublin), the UK population increased in many large urban centres during this time. On social classes in the UK, a similar trend to Ireland is visible, in that census data from 1951 to 1991 (at 10 year intervals) shows more workers moving into professional or similar occupations and less unskilled workers which 'reflected the continuing growth in professional and managerial occupations' (Royle, 2012: 109). This, like Ireland, was 
also reflected in general wage growth - for example, real wages grew by $1-3 \%$ during the period from 1964 to 1996, declining only in the mid-1970s (ONS, 2014).

In summary, although our description above of the Irish and UK economy and society are brief, a broad similarity is apparent. As noted earlier, Scott (2014) suggests various institution levels (such as the economy and society) can influence other levels (such as organisations, organisational fields) - which is reflected in our hypothesis presented earlier. However, to explore each and every such influence over a period of time is a substantial volume of work, and is unlikely to yield incremental findings. Thus, taken into account the objective of the paper, similar to Moreno and Cámara (2014) we utilise periods of time in this study. Given our descriptions of economy and society above, the periods we utilise are as follows: (1) 1948-1959, which we term post-war gloom and doom; (2) 1960-1972, which we term growth (3) 1973-1984, which we term the EEC and more gloom; and finally, (4) 1985-1996 which we term more growth. Table 2 summarises these four periods and their main characteristics. As noted earlier, the similarity between economic and societal conditions between Ireland and the UK during our analysis period is apparent. We thus utilise periods similar to those given by O'Gráda (1997) with a view that the Guinness company had major brewing operations in Dublin, Ireland, and as a brand is viewed as one of Irish heritage (see for example, Muzellec and Lambkin, 2008).

[Insert Table 2 around here] 


\section{Method}

Content analysis is useful for describing trends and studying how similar issues are treated differently over time (Berelson, 1971). Most studies using thematic content analysis in accounting in general have focused on analysing the presence or absence of one or more attributes or particular topics (Kothari et al., 2009; Neimark and Tinker, 1986). Most such studies typically codify only specific aspects of the source document ${ }^{10}$. In contrast, the present study codifies the entire source document, in our case, the Chairman's Statement. More specifically in the accounting history literature, as Previts et al. (1990: 148) noted, content analysis had 'emerged as an addition to the quantitative methodologies available for accounting history research'. For instance, Neimark (1983) analysed ten themes from the annual report of General Motors over a sixty-year period. The themes used were driven by 'technological social, organizational and ideological innovations that are widely regarded as being characteristic of the period from 1916 through 1976' (Neimark, 1983: 19). Her analysis did not intend to codify the entire source document, rather to find evidence of the themes just described. This paper follows Neimark's (1983) approach, but in contrast, we will (below) propose themes based on extant literature and perform a more detail statistical analysis, thus building on the groundwork of Neimark (1983). However, despite the potential usefulness of content analysis to accounting history research as suggested by Previts et al. (1990), a review of published articles by Spraakman and Quinn (2018) from 2005-2015 in three leading accounting history journals ${ }^{11}$, reveals 
few papers which have adopted a content analysis method. A study by Badua and Watkins (2011) analyses the content of articles on accounting information systems (AIS), in essence to bring out themes of AIS research and to show the potential of content analysis as a useful method in accounting history research. While using some content analysis methods, Badua and Watkins' (2011) work is less similar to the nature of the present study. A study by Moreno and Cámara (2014) is closer in nature, as it uses a content analysis method to identify themes over time in some corporate documents, one of them similar to the Chairman's Statement; coincidentally they also study the brewing sector. Their study identifies seven themes, and analyses changes in documents content across these themes based on five institutional stages of the turbulent Spanish political history in the twentieth century. The current study similarly uses time periods, which we have outlined in the previous section mainly based on economic and social conditions because, in contrast to the Spanish case, the Irish and UK political landscapes were quite stable in the period of study ${ }^{12}$. In addition, the present study is based on a well-known multinational company, whereas Moreno and Cámara's (2014) work is on a much smaller brewery and organisation.

There are several ways to utilise archival evidence to tell a story of change and/or stability in an organisation (Ó hÓgartaigh and Ó hÓgartaigh, 2004). In this paper, we provide a thematic content analysis based on the Chairman's Statement of Guinness from 1948 to 1996, which are available at the Guinness archive in Dublin. The Chairman's 
Statement is the most widely read section of the annual report (Bartlett and Chandler, 1997) and it functions as a summary of the annual report (Balata and Breton, 2005) ${ }^{13}$. Similar to Moreno et al. (2019), the study starts in 1948 as this is the first year the Chairman's Statement was regularly available and ends in 1996, as this was the last annual report produced independently by Guinness - the company merged with Grand Metropolitan to form Diageo plc in 1997. Consequently, 49 Chairman's Statements were examined. Sample pages from three of these documents are shown in Appendix 1.

Weber (1985) describes the stages of a content analysis as 1) define the recording unit; 2) define the categories; 3) test coding of a sample of text; 4) assess accuracy or reliability; 5) revise coding rules; 6) return to step 3 if necessary; 7) code the entire text; and finally 8) assess achieved reliability or accuracy. We followed these general stages. In our study, following Krippendorff (1980), the Chairman's Statement constitutes the sampling unit ${ }^{14}$. As we codify all of each sampling unit, and due to extent of the timeseries of documents to be encoded, we selected the paragraph as the recording (and context) unit ${ }^{15}$. Software is often utilised when the recording unit is a word (Davis et al., 2012; Frazier et al., 1984). However, manual coding is more commonly used in the case of topics, paragraphs, sentences or whole documents (Cormier et al., 2005; Noble et al., 2002). Here, we adopt manual coding, which is considered to more appropriate for a thematic analysis (Wallace et al., 1992) and it is also preferred for complex categorisation (Linderman, 2001). 
To construct a category system to code the recording units, we initially examined theoretical literature on content analysis for guidance (Bardin, 2002; Holsti, 1969; Krippendorff, 1980). We then adopted the seven categories used by Moreno and Cámara (2014) as a starting point, as shown in Table 3. They codified the longitudinal information of another brewing company. For our research objective, Moreno and Cámara's (2014) category system is comprehensive and mutually exclusive and using it also allows comparison with previous research. However, the definition of the categories required extension and clarification as our work proceeded. Moreno and Cámara (2014) studied a smaller Spanish brewery and the larger size and more global nature of Guinness were the main drivers of adapting the category definitions. To test the reliability of the system, we opted for a test-test process, also known as reproducibility. It can be defined as the degree to which the process can be replicated by different analysts (Krippendorff, 1980). Initially, we independently categorised a random sample of 14 Chairman's Statements and the coefficient of agreement reached was 55\%. Differences were discussed and the category definitions clarified accordingly. We then randomly chose and independently categorised a second sample and the agreement reached was $71 \%$. As the agreement reached was not sufficiently high, we again discussed differences, reached an agreement and further clarified the category definitions. We again randomly chose and independently categorised another different sample. On this third round, the agreement reached was 90\%. The final agreed category definition scheme is shown in Appendix 2. 


\section{[Insert Table 3 around here]}

Apart from the definition and description of categories, we adopted the following procedures and rules for the content analysis. First, relative frequency is used as the counting unit. Second, we adopted coding rules as follows: a paragraph can comprise

more than one category; multiple categories within the same paragraph have equal weight; every paragraph has the same importance; photographs and graphics are coded as if there were paragraphs. Using these rules and the final category system as per Appendix 2, all Chairman's Statements from 1948 to 1996 were manually coded.

Finally, once the content analysis and associated statistical analysis was complete, we set out analysing the results in terms of institutional factors (economic, societal and other levels - see later). This allows us to augment the content analysis itself and offer richer explanations for patterns of change and/or stability in corporate information (within the Chairman's Statement) behaviour across the periods.

\section{Results of thematic analysis}

We now detail the results of our thematic analysis. The analysis was performed according to the four periods described above, namely: post war gloom and doom (1948-1959); growth (1960-1972); the EEC and more gloom (1973-1984); more growth (1985-1996). Table 4 summarises the number of paragraphs coded from the Chairman's Statements of the analysis period. A total number of 1,461 of paragraphs (including photographs and 
graphics) were codified. $65 \%$ of them were codified with only one category. $25 \%$ of the paragraphs were codified with two categories. Less than $5 \%$ of the paragraphs were codified by three of four categories. $6 \%$ of the codifications represented photographs and graphics.

\section{[Insert Table 4 around here]}

Table 5 shows the relative importance and tendency of the categories. Only two categories have a relative presence over $20 \%$ on average during the entire analysis period, namely Organisational aspects and Results. The categories with the least relative presence (around 5\%) are Investments, Social aspects and Future-forecast. The categories Formal aspects and Context occupy an intermediate position during the period. In terms of tendencies for the whole period, the categories Context, Organisational aspects and Future-forecast show an increasing presence, in contrast to the categories Formal aspects, Social aspects, Investments and Results. Among them, the category Futureforecast exhibits the strongest positive variation for the whole period, while the category Investments shows the strongest negative variation.

\section{[Insert Table 5 around here]}

To statistically analyse the evolution of the Chairman's Statement during the different periods, we carried out non-parametric tests as the categories failed to adhere to the requirements of normality and homoscedasticity. Table 6 summarises the significant 
differences in the categories across the four periods. The different tests are shown in detail in Appendix 3. There are statistically significant differences over the four periods in the categories Formal aspects, Social aspects, Investments and Future-forecast according to the Kruskal-Wallis test. On the specific transitions (from one period to another), the transition between the third and fourth periods exerted the greatest impact on the content of the Chairman's Statement, as there is a statistically significant difference in three of the seven categories, namely Social aspects, Investments and Future-forecast (see Appendix 3 for more detail) according to the Mann-Whitney test. Using this same test, the transition between the first and second periods portrays a similar change in two categories (Formal aspects and Context), and between the second and third periods only in one category (Investments).

\section{[Insert Table 6 around here]}

The evolution of each category during the four periods is shown graphically in Appendix 4. The category Organisational aspects shows stable behaviour across the four periods, being the most important category in every period with a relative presence above $20 \%$ in every year - with the exception of 1980. Stable behaviour is also shown in the Results category. These two highest presence categories do not show significant changes either over the whole period or in any transition (see Table 6). 
In the first period (post war gloom and doom, 1948-1959), the Social aspects category exhibits its highest presence, potentially reflecting an attempt to alleviate strict fiscal measures in the Irish economy, especially after 1953. As an example:

'All our employees and staff have had a month's bonus and over $£ 150,000$ was paid as a special rebate to our customers. At the same time we have decided to increase the pensions of nearly all but very recent pensioners, as some alleviation of the greatly increased costs they have to face since their pensions were fixed' (Chairman's Statement, 1954).

In the second period (growth, 1960-1972), Social aspects and Formal aspects show a reduced relative presence. In contrast, Context and Investments show increased presence, most likely as a consequence of expansionary economic conditions and the resulting improvement in the trading conditions. For example, the following extracts give a flavour of the context (two first extracts) and investments (third extract):

'Throughout the year we have had to meet the United Kingdom surcharge payable on all imports of Irish brewed stout and lager. I am glad to say that this particular impost ceased on 30th November. Even with the Market Development Grants made by the Irish Government during this period, the surcharge has cost us a great deal of money' (Chairman's Statement, 1966).

'In the Republic of Ireland we had been showing welcome growth in all sections of the beer market' (Chairman's Statement, 1968). 
'Of this over half relates to three major projects-the new Nigerian Brewery which will open early in 1963, the Dundalk lager brewery, and the Dublin cask metallisation programme now virtually completed. We have also spent further large sums on improvements and renovations at the Dublin and Park Royal Breweries and on our transport fleets' (Chairman's Statement, 1962).

In the third period (EEC and more gloom, 1973-1984), the entry of Ireland and the UK to the EEC drives a slight increase in Organisational aspects, as more general commercial information was included in the Chairman's Statement, for example:

'Considerable progress has been made in building up our distribution arrangements in Western Europe. In Germany, distribution of both our bottled and draught products has been taken on by the Dortmunder Kronen Brewery in North Rhine Westphalia and by the Haake-Beck Brewery of Bremen in the north. In France, the Brasseries Kronenbourg of Strasbourg have taken on the distribution of bottled and draught Guinness for metropolitan France. These arrangements will provide the opportunity to improve our position significantly in two of our major Continental markets' (Chairman's Statement, 1975).

During this period, the decrease in Investments and in Social aspects is noteworthy. The decrease of the former, to virtually nothing, was quite significant from 1979 on. This appears linked to general economic conditions, with the company being restrictive on new investments, as well as carrying out a programme of divestment to focus on brewing activities, for example: 
'High interest rates, large increases in costs, and the prospects of generally recessionary conditions all over the world point to a difficult year [...] The current very high interest rates do demand a very careful selection of expansion projects' (Chairman's Statement, 1979).

'I am certain that we should have some non-brewing investments but these results and the events which they reflect, have presented your Boards with challenges which we have met with vigour' (Chairman's Statement, 1981).

The fourth period (more growth, 1985-1996) also shows an increasing importance of Future-forecast, when the Chairman's Statement is most focused on the future. There is almost no mention of Investments during this period. The future focus is a consequence of a more unstable business environment (despite economic growth in general), for example:

'Our strategy is straightforward: we will continue to concentrate on our two core businesses of spirits and beers and to benefit from this clear focus. Our future lies in further developing the appeal of our outstanding portfolio of brands with consumers all over the world. We will do this by improving our marketing, sales and distribution activities, and by responding to changing market and consumer demands through a closer understanding of their needs. This is a strategy of organic growth. Additionally, we will continue to look for suitable opportunities to work with appropriate companies to expand and improve our business through partnership or acquisition' (Chairman's Statement, 1992). 
Social aspects also show an increasing presence in this period, due mainly to the increased emphasis on staff welfare (at larger companies in particular), awareness of alcoholism and the natural environment during this time, for example:

'The encouragement of moderate drinking follows logically from our focus on value. We have worked to promote moderation both through publications [...]. In the United Kingdom, we have long supported the many initiatives and Brewers' Society which have been designed to increase the public's awareness of the benefits of moderate drinking. We are working with similar bodies in other key markets' (Chairman's Statement, 1989). 'The environment is subject of increasing importance to us all. We rely on natural raw materials, and without these your Company simply could not exist. As a result the protection of the environment is one of our major objectives' (Chairman's Statement, 1992).

In summary, although the statistical analysis and examples given thus far show some changes in the content of the Chairman's Statement, over the entire analysis period as seen in Appendix 4 there is, by and large, relatively stable content. This is despite a relatively long timeframe and a changing business, social and economic environment. Accordingly, we cannot accept in full our research hypothesis (H1) that the content of the Chairman's Statement changes over time due to different contexts. We can partially accept it, and now we examine some potential institutional influences which may provide richer explanations of what our content analysis reveals. 


\section{Adding an institutional lens}

From the content analysis above, we have determined some changes in the content of the Chairman's Statement over time; however, stability is also apparent in some categories. Regardless of whether we found change or not, an isolated content analysis with associated statistical tests cannot interpret trends. Thus, as outlined earlier, we now offer some additional interpretation of the changes and/or stability in the external disclosures of the Chairman's Statement drawing on institutional concepts and contexts. We have already noted how Scott (2014: 106) suggests various levels of institutions, from macro to micro level as follows; 'world system, societal, organizational field, organizational population, organization, organizational subsystem, ${ }^{16}$. These various levels are often the subject of specific schools of institutional thought, aligned with the three pillars of institutions as presented by Scott (2014). Thus, for example, institutional sociology is typically associated with the organisational field level and the normative pillar. The brief history and context presented earlier provides some insights into the economic (world system), societal, organisational field (the UK/Irish brewing sector) and organisation (Guinness) levels. Arguably too, we have some insights into an organisational subsystem - executive management - through the Chairman's Statement. These insights provide clues of potential institutional factors from various levels which could have affected Guinness corporate narratives during the timeframe of our analysis. As already noted, in common with many prior studies, we draw on specific elements from strands of 
institutional theory to provide an explanatory lens - namely Scott's (2014) depiction of the interactions of institutional levels and the three pillars of institutions (see Table 1).

As revealed in our content analysis, there are statistically significant differences over the periods in the categories Formal aspects, Social aspects, Investments and Futureforecast. We thus begin our institutionally informed discussion here. The Formal aspects category (see Appendix 2) includes more internal procedural matters (approval of accounts, retirements, deaths of key staff, agenda, etc.) and is less likely to be impacted by institutional forces from outside the organisation. Examining the content analysis in detail, the vast majority of such content relates to retirements and to deaths of former staff. The nature of this content is likely the reason for no significant changes either from the second to the third period or from the third to the fourth period in this category (Table 6). However, the significant decrease in the second period in this category may be due to an organizational subsystem level factor, whereby the practices around the preparation and content of the Chairman's Statement began to become accepted (or institutionalised), and other categories gained more importance in terms of inclusion. However, a more micro level analysis of internal institutionalised practices would be required to reveal the precise reason, which is beyond the scope of this study.

Social aspects (see Appendix 2) relates to the worker-related matters and company actions toward society. As noted in the content analysis, this category is significantly different over the entire period. In the first period, much of this category is explained by 
worker-related matters (see earlier). It became a greater feature again during the fourth period, having declined during the previous two periods. Extracts from the 1989 and 1992 Chairman's Statement shown earlier suggest coercive and/or mimetic mechanisms may be at play here. Tougher laws on alcohol consumption globally - a regulative force as per Table 1, through a coercive mechanism - and pressures from the societal level and the organisational field level to be environmentally and socially aware (for example, the move to responsive corporate social responsibility narrative from 1980 s - see Owen, 2014) are key factors which influenced the narrative to change. It should be noted that at this time pressures to be more environmentally and socially aware constituted a mimetic mechanism, as such reporting/commentary was not mandatory. Thus, there is a downward institutional influence in the fourth period from the societal and organisational field levels to the Guinness organisation, and this is evident through the commentary in the Chairman's Statements.

Investments (see Appendix 2) relates to new and extended productive capacity. For the first three periods, it would seem that the narrative of the Chairman's Statement does indeed reflect influence from the world system institutional level. One would expect the level of investment to increase under improving economic conditions, as disposable incomes rise. Population growth, ultimately creating a larger market over time, would also drive increased investment. As revealed by the content analysis (see Appendix 4), the highest level of narratives on the Investment category is during the 1960-1972 period, 
which we term growth. During this time both the UK and Irish economies did indeed experience growth, as revealed earlier. Thus, there appears to be a trickle-down effect from the world system level (increased growth) to the organisational level and the organisational subsystem level (new investment to meet demand), and the resulting investments stem from a cognitive reaction by Guinness management to a growing economy. This period of time also included the merger-mania period as mentioned by Gourvish and Wilson (1994), and thus arguably, there is a potential mimetic influence from the organisational population (i.e. breweries) level too. Interestingly, the final period (1985-1996, more growth) does not portray a similar pattern. This can be potentially explained by factors such as the end of the merger-mania period (less influence from the organisational field and organisational population) and scale achieved by Guinness at the time - thus, at the organisational subsystem level there was a cognitive basis of compliance that company growth e through acquisition from the 1960s was at an end ${ }^{17}$.

Future-forecast (see Appendix 2) relates to narrative on future plans, strategies and projects. As can be seen in Appendix 4, Future Forecast became a more significant feature during the fourth period in contrast to any previous period. The change in Futureforecast may reflect generally improving economic conditions during the more growth period, and thus influences from the world system institutional level. However, given our points above on Investment, we cannot attribute the greater degree of Future-forecast narrative to forward-looking investment. Two other institutional factors may explain this 
increase in this category. One is the increased regulation of financial statements and communications from public companies from the late 1970's/early 1980's - a coercive mechanism, stemming from the world system institutional level. Although it should be noted that such regulation leaves managers relatively free to shape some textual parts of annual reports (Brennan and Merkl-Davies, 2013). A second potential influence comes from the organisational sub-system level in the form of the Board of Directors. As noted earlier, the first non-family Chairman of Guinness, Norman McFarlane was appointed in 1986. This new appointment, and a changing composition of the Board with less Guinness family members, implied values from external board members - with experience outside the Guinness company - were infused within the company. These new values can be construed as both a normative and mimetic mechanism (profession directors with a shared logic of how to run a company board).

We turn now to other aspects revealed by the content analysis as having no significant difference over time. Organisational aspects and Results are the most prevalent and stable elements of the Chairman's Statement during the analysis period (see Tables 5 and 6, Appendix 4). The category Organisational aspects includes items which relate to internal (mainly operational) decisions made by the firm (see Appendix 2). As noted as some examples above were discussed, from an institutional perspective an organisation can be affected by forces from other institutional levels (Scott, 2014). These forces could imply Guinness changed how it operated, and in turn, we could expect to see 
this reflected in the Organisational aspects category. However, the content analysis shows little change in this category - and no changes can be deemed as statistical significance (see Table 6). This is somewhat surprising, as from an institutional perspective it is expected that change is more likely to happen over longer timeframes for example, Williamson (2000: 597) suggests the 'rules of the game' take 10-100 years to change. Likewise, the Results category reveals no statistically significant difference over the analysis period. In this case, one explanation for stable narrative may be the fact that Guinness was a profitable company from incorporation in 1886 to the end of our analysis period (1996), and in general a dividend was paid to shareholders. In addition, the Context category also showed no statistically significant difference over the whole period. However, it showed one significant change from the first to the second period (Table 6). As per Appendix 2, the Context category includes mention of economic, political and social context in the Chairman's Statement. From an institutional perspective, such contextual factors represent occurrences at higher institutional levels as already outlined, and we have given a summary of economic and social factors during the analysis period. However, again from an institutional perspective, the type of narrative the content analysis captures as Context are likely to be reflected in other categories - for example in more or less narrative on Investment, which may be as a result of changing economic conditions as suggested earlier. Having said this, the relatively stable nature of the Context category revealed in the content analysis does suggest that Guinness (through 
the Chairman's Statement) were consistently aware of economic, political and social factors. This consistency was only broken from the first to the second period. The strong economic expansion and the improvement in the international trade, examples of world system level institutional factors, was reflected by the company through a significant increase in information about context.

As hinted above, it is somewhat surprising that the Organisational aspects category remained quite stable during the analysis period. Indeed, as mentioned, the content of the Chairman's Statement is relatively stable overall (see Appendix 4). This is to an extent in contrast to the findings of Moreno and Cámara (2014). Their study was over a longer time frame (1928-1993), in a different context and of a much smaller Spanish organisation. There are thus many potential reasons for differences in reporting narratives between this study and Moreno and Cámara (2014). Here, the higher relative stability of the categories over time in the Guinness Chairman's Statement is by itself an interesting finding. The period of our analysis is relatively long, includes economic and societal forces (for example, violence in Northern Ireland, new alcohol legislation, new taxes, a changing industry sector, growth, recession, rising incomes). One would logically expect such items, construed here as forces from various institutional levels, to be apparent through narratives such as the Chairman's Statement of a large company like Guinness. Using Scott's (2014) notion of institutions, we can offer a potential explanation for this relative stability. Although we have offered explanations of potential institutional 
factors from various levels which may have influenced content of the Chairman's Statement, we must not forget that the organisation itself is an institution and internal factors (at the organisation and organisational subsystem levels) may be at play. In other words, the organisation itself as an institution may be sufficiently institutionalised to remain stable. Based solely on our analysis of the Chairman's Statement, we can offer two potential factors which portray Guinness as a strong institution over time. First, as revealed when we analysed the Formal aspects category, the Chairman's Statement was presented/signed by the by Earl of Iveagh for the most part. This title is held by the Guinness family, and was occupied by the 2nd and 3rd Earl during our analysis period. Our analysis of the Organisational aspects of the Chairman's Statement also reveals many Guinness family members being appointed and re-appointed to the Board over time - as mentioned earlier it was not until 1986 that a non-Guinness family member was appointed as Chairman. Thus, it is arguable that the organisation itself, and its subsystem were relatively stable, and quite institutionalised, given the stability of the Board and management in general. Second, as per the Results category, the company remained profitable each and every year of the analysis period. This suggests a set of organisational practices existed (at the organisational subsystem level) which were consistent and stable, again suggesting institutionalised practices. These two potential explanatory factors are reflective of the stability of Guinness as a family company over time. Stability in terms of founding families of a firm has been noted as improving firm performance (see for 
example, Anderson and Reeb, 2003), and stability of, for example, management accounting practices at Guinness has been noted previously (Quinn, 2014).

In summary, the use of an institutional lens allows us to provide some qualitative interpretation for reasons in the change/stability of the Chairman's Statement over and above that of the statistical analysis. The interpretations are of course tentative, and further more in-depth study would be required to confirm or refute them.

\section{Concluding comments}

The paper contributes to the accounting history literature by analysing longitudinally how institutional forces can affect reporting practice over a long period of time. Longitudinal analyses are appropriate to study changes over time (Dawson, 2003), however corporate reporting studies over long periods of time are unusual (Guthrie and Parker, 1989; Neimark and Tinker, 1986), because they involve the availability and the collection of long series of data. We have conducted a longitudinal content analysis of discretional corporate narratives, augmented by an institutionalist lens to link findings to various contextual factors. The results show that the external institutional factors involve some variations on the themes covered by the disclosure over time, but in general the content is relatively stable. Apart from the extensive holdings of the corporate archives of Guinness, the analysis of this well-known multinational company also offers unique conditions as it got consistent profits over time. 
The relative stability found may be explained as the organisation itself is an institution that may be sufficiently institutionalised to remain relatively stable, and to some extent resist change. That is, Guinness may be an example of a strong institution over time. Guinness family members were appointed and re-appointed to the Board over time. Even the Chairman's Statements were signed across many years using the same title of nobility (transmitted across different generations). Moreover, the company remained profitable every year of the analysis period, and thus could be deemed a successful organisation from a financial perspective. This suggests a set of organisational practices that were consistent and relatively stable over time, including the relatively stable nature of corporate reporting (in the form of the Chairman's Statement). This finding is partly counter to the hypothesis of this study. The combination of continued profitability and relatively apparent buffering from external institutional forces evidenced in the disclosure is an interesting insight. It contributes to the debate about the behaviour of organisations, i.e. reflecting and changing with external environment, or buffering their internal practices from external turbulence. General business literature often favours the former point (see for example, Englehardt and Simmons, 2002). While we are not suggesting here that the themes of the externally-oriented corporate information in Guinness did not change during the period in question, our findings show that a key corporate disclosure report conveys a sense of a stable and successful (family) firm. 
Our study has built on previous thematic content analyses in the accounting history literature. The findings have been interpreted under an institutional lens. Specifically, we have noted potential institutional forces from various institutional levels described by Scott (2014), which may explain the change and stability in the narrative of the Chairman's Statement at Guinness. Utilising an institutional lens has allowed us to offer some potential explanations which provide more richness than content analysis alone. This offers not only some tentative interpretation, but also a sensitising mechanism to categorise issues of interest for more detailed future study using in-depth qualitative approaches. While we acknowledge that conducting a thematic content analysis as here is somewhat time consuming, it is likely that the analysis will be time well spent and produce many areas of interest from an organisation's history.

There are limitations to our study, the first being the case itself. Guinness, like any firm, is subject to potentially unique and context specific factors. Second, while we have offered some explanations of possible mainly external institutional forces on the narratives of Guinness, internal factors may also affect content of the Chairman's Statement - for example, mergers, changes in leadership, management style, etc. Such additional factors are beyond the scope of this paper. Third, although we did not find any direct evidence of the involvement of professional writers in the preparation of the Chairman's Statement, a potential change over time from the preparation in-house to assistance by advertising or public relations agencies could lead to a drift in the 
institutional norms, affecting the analysis. Fourth, disclosure may not provide a reliable picture of internal organisational behaviour and/or it can be used for impression management purposes (see for example, Brennan and Merkl-Davies, 2013; Leung et al., 2015; Moreno et al., 2019). However, this is not within the focus of this paper. In addition, the use of the Chairman's Statement is a strength to favour possible further comparison in future research. Fifth, the process of content analysis is affected by subjective decisions (Laine, 2009) such as the category system, the unit of analysis, and the coding (this latter in the case of manual coding). However, we have endeavoured to control reliability as outlined in the methods section. Last, as also noted by Moreno and Cámara (2014), our statistical analysis has used representative values for the quantity, and not the quality, of information in each category. The limitations noted above should be balanced against opportunities content analysis of corporate narratives presents, especially when limited archival material is available. Although we have based our findings on a specific framework, we would encourage future researchers to adopt other theoretical methods to provide rich longitudinal studies of corporate narratives using content analysis.

\section{Notes}


1 DiMaggio and Powell (1991: 65) define an organisational field as 'organizations that in aggregate constitute a recognised area of institutional life; key suppliers, resource and product consumers, regulatory agencies and other organizations that produce similar products or services'. In this paper, the Irish/British brewing industry is considered an organisational field.

2 World system refers to global, national and transnational levels.

3 This process of concentration in the brewery sector has not been a single case, but has occurred in many other countries in the twentieth century, as in Spain (Moreno, 2013).

4 Allied, Bass, Courage, Scottish \& Newcastle, Watneys, Whitbread - see Gourvish and Wilson (1994).

5 They also provide a summary of the technological economies achieved.

6 Other authors provide similar analysis of the Irish economy during our analysis period, for example, Bielenberg and Ryan (2012) and Giblin et al. (2013).

7 In the case of Guinness, joining the EEC also could be construed as an opportunity to reduce reliance on the UK market.

8 See http://www.cso.ie/en/releasesandpublications/ep/p-hes/hes2015/aiw/.

9 According to the Global Status Report on alcohol and health (WHO, 2018), beer consumption in Ireland rose steadily from 1960 to 1975, then declined until about 1986, and rose again from 1987 to 2000 . While statistics on consumption prior to 1960 are less accessible, Walsh (1987) suggest the period from 1920 to 1960 was not one of high consumption, and he also notes increased consumption from 1960.

10 As exceptions, see Collins et al. (1993) and Moreno and Cámara (2014).

11 Accounting History, Accounting History Review and The Accounting Historians Journal.

12 Although we have basically excluded the political environment as a potential influencing factor on institutional phenomena, any major political policy changes or choices would have ultimately been reflected through economic and social factors.

13 There could be some debate about the authorship of the Chairman's Statement. However, in any case, it would be reflecting the point of view of the company. In this particular case, we raised a query with the Guinness archive in an effort to determine if professional report writers were ever used to support to prepare the Chairman's Statement. No evidence of this was found.

14 For a review of the main sampling and recording units used in previous accounting content analysis studies, see Jones and Shoemaker (1994).

15 Also used by Karlinsky (1981) and Moreno and Cámara (2014).

16 Dillard et al. (2014) similarly present a framework which notes that the dynamics of institutions can occur at three levels namely, the economic and political level, organisational field level and organisational level. 
17 As our study is limited to the Chairman's Statement, this is partially supposition on our part. However, post 1996, the Diageo Group has divested several brands and prior acquisitions. For example, the Annual Reports of Diageo from 1997 to 2000 reveal divestments in excess of $£ 2$ billion. 


\section{References}

Primary sources

Archive of Arthur Guinness, Son \& Company Ltd, St. James's Gate, Dublin, Ireland. Files utilised: Annual Reports and Financial Statements, 1948-1996.

Secondary sources

Abrahamson E and Park C (1994) Concealment of negative organizational outcomes: An agency theory perspective. Academy of Management Journal 37(5): 1302-1334.

Acheson GG, Coyle C and Turner JD (2016) Happy hour followed by hangover: financing the UK brewery industry, 1880-1913. Business History 58(5): 725-751.

Adelman J (2017) Food in Ireland since 1740. In: Biagini EF and Daly ME (eds) The Cambridge Social History of Modern Ireland. Cambridge: Cambridge University Press, pp. 233-243.

Anderson RC and Reeb DM (2003) Founding-Family Ownership and Firm Performance: Evidence from the S\&P 500. Journal of Finance 58(3): 1301-1328. 
Badua FA and Watkins AL (2011) Too young to have a history? Using data analysis techniques to reveal trends and shifts in the brief history of accounting information systems. Accounting Historians Journal 38(2): 75-103.

Balata P and Breton G (2005) Narratives vs numbers in annual report: are they giving the same message to the investors? Review of Accounting and Finance 4(2): 5-14.

Bardin L (2002) Análisis de contenido, third edition. Madrid: Akal.

Bartlett SA and Chandler RA (1997) The corporate report and the private shareholder: Lee and Tweedie twenty years on. British Accounting Review 29(3): 245-261.

Baskerville RF, Bui B Fowler CJ (2014) Voices within the winds of change: The demise of KMG Kendons. Accounting History 19(1/2): 31-52.

Berelson B (1971) Content analysis in communication research, facsimile of 1952 . New York: Hafner.

Bielenberg A and Ryan R (2012) An Economic History of Ireland Since Independence, vol. 149. London: Routledge.

Brennan, NM and Merkl-Davies DM (2013) Accounting narratives and impression management. In: Jack L, Davison J and Craig R (eds) The Routledge companion to accounting communication. London: Routledge, pp. 109-132. 
Burns J (2000) The dynamics of accounting change: Inter-play between new practices, routines, institutions, power and politics. Accounting, Auditing and Accountability Journal 15(5): 566-595.

Burns J and Scapens RW (2000) Conceptualizing management accounting change: an institutional framework. Management accounting research 11(1): 3-25.

Campbell D and Abdul Rahman MR (2010) A longitudinal examination of intellectual capital reporting in Marks \& Spencer annual reports, 1978-2008. British Accounting Review 42(1): $56-70$.

Caria AA and Rodrigues LL (2014) The evolution of financial accounting in Portugal since the 1960s: A new institutional economics perspective. Accounting History 19(1/2): $227-254$.

Carmona S and Macías M (2001) Institutional pressures, monopolistic conditions and the implementation of early cost management practices: the case of the Royal Tobacco Factory of Seville (1820-1887). Abacus 37(2): 139-165.

Cleary P, Quinn M and Moreno A (2018) Socioemotional wealth in family firms: A longitudinal content analysis of corporate disclosures. Journal of Family Business Strategy. Epub ahead of print 26 December 2018. DOI: 10.1016/j.jfbs.2018.11.002. 
Colasse B and Pochet C (2009) The genesis of the 2007 Conseil National de la Comptabilité: A case of institutional isomorphism? Accounting in Europe 6(1): 25-55.

Collins W, Davie ES and Weetman P (1993) Management discussion and analysis: an evaluation of practice in UK and US companies. Accounting and Business Research 23(90): 123-137.

Cormier D, Magnan M and Van Velthoven B (2005) Environmental disclosure quality in large German companies: economic incentives, public pressures or institutional conditions? European Accounting Review 14(1): 3-39.

Courtis JK (1998) Annual report readability variability: tests of the obfuscation hypothesis. Accounting, Auditing and Accountability Journal 11(4): 459-471.

Davis AK, Piger JM and Sedor LM (2012) Beyond the numbers: measuring the information content of earnings press release language. Contemporary Accounting Research 29(3): 845-868.

Dawson P (2003) Reshaping Change: A Processual Perspective. London: Routledge.

Dennison SR and MacDonagh O (1998) Guinness 1886-1939: from incorporation to the Second World War. Cork: Cork University Press. 
Dillard JF, Rigsby JT and Goodman C (2004) The making and remaking of organisation context: Duality and the institutionalization process. Accounting, Auditing and Accountability Journal 17(4): 506-542.

DiMaggio WW and Powell PJ (1991) The Iron Cage Revisited: institutional isomorphism and collective rationality in organizational fields. In: Powell PJ and DiMaggio WW (eds) The New Institutionalism in Organizational Analysis. Chicago: University of Chicago Press, pp. 63-82.

Englehardt CS and Simmons PR (2002) Organizational flexibility for a changing world. Leadership \& Organization Development Journal 23(3): 113-121.

Fitzgerald J (2017) Irish demography since 1740. In: Biagini EF and Daly ME (eds) The Cambridge Social History of Modern Ireland. Cambridge: Cambridge University Press, pp. 7-24.

Fowler CJ and Keeper T (2016) Twenty years of Accounting History (1996-2015): Evidence of the changing faces of accounting history research. Accounting History 21(4): 389418.

Frazier KB, Ingram RW and Tennyson BM (1984) A methodology for the analysis of narrative accounting disclosures. Journal of Accounting Research 22(1): 318-331. 
Gervais P and Quinn M (2016) Costing in the early Industrial Revolution: gradual change to cost calculations at US cloth mills in the 1820s. Accounting History Review 26(3): $191-217$.

Giblin T, Kennedy K and McHugh D (2013) The economic development of Ireland in the twentieth century. London: Routledge.

Gourvish TR and Wilson RG (1994) The British Brewing Industry 1830-1980. Cambridge: Cambridge University Press.

Guthrie J and Parker LD (1989) Corporate social reporting: A rebuttal of legitimacy theory. Accounting and Business Research 19(76): 343-352.

Hiebl MR, Quinn M and Martínez Franco C (2015) An analysis of the role of a Chief Accountant at Guinness c. 1920-1940. Accounting History Review 25(2): 145-165.

Higgins E, Toms S and Uddin M (2016) Vertical monopoly power, profit and risk: The British beer industry, c.1970-c.2004. Business History 58(5): 667-693.

Holsti OR (1969) Content analysis for the social sciences and humanities. Reading, MA: Addison-Wesley.

Irish Times (1959) Drogheda brewery sold for £130,000, 25 February, 3.

Irish Times (1964) Arthur Guinness obtains control of Guinness, 27 June, 4. 
Jones MJ and Shoemaker PA (1994) Accounting narratives: a review of empirical studies of content and readability. Journal of Accounting Literature 13: 142-184.

Karlinsky SS (1981) Complexity in the federal income tax law attributable to the capital gain and loss preference: a measurement model. PhD Thesis, New York University.

Kothari SP, Li X and Short JE (2009) The effect of disclosures by management, analysts, and business press on cost of capital, return volatility, and analyst forecast: a study using content analysis. The Accounting Review 84(5): 1639-1670.

Krippendorff K (1980) Content analysis. An Introduction to its methodology. Beverly Hills, CA: Sage.

Laine M (2009) Ensuring legitimacy through rhetorical changes? A longitudinal interpretation of the environmental disclosures of a leading Finnish chemical company. Accounting, Auditing and Accountability Journal 22(7): 1029-1054.

Langton J and West B (2016) One hundred years of annual reporting by the Australian Red Cross: Building public trust and approbation through emotive disclosures. Accounting History 21(2/3): 185-207.

Leung S, Parker L and Courtis J (2015) Impression management through minimal narrative disclosure in annual reports. British Accounting Review 47(3): 275-289. 
Linderman A (2001) Computer content analysis and manual coding techniques: a comparative analysis. In: West MD (ed) Theory, method and practice in computer content analysis. Westport, CT: Ablex, pp. 97-109.

Lynch P and Vaizey J (1960) Guinness's Brewery in the Irish Economy 1759-1876, Cambridge, UK: Cambridge University Press.

Meyer JW (1986) Social environments and organizational accounting. Accounting, Organizations and Society 11(4/5): 345-356.

Meyer JW and Rowan B (1977) Institutionalized organizations: Formal structure as myth and ceremony. American Journal of Sociology 83: 340-363.

Miller P (1994) Accounting as social and institutional practice: An introduction. In: Hopwood AG and Miller P (eds) Accounting as Social and Institutional Practice. Cambridge: Cambridge University Press, pp. 1-39.

Moll J, Burns J and Major M (2006) Institutional theory. In Hoque Z (ed) Methodological issues in Accounting research: Theories, methods, and issues. London: Spiramus, pp. $108-130$. 
Moreno A (2013) El sector cervecero español en el siglo XX. Una visión desde dentro: El Alcázar. Investigaciones de Historia Económica-Economic History Research 9(3): $165-174$.

Moreno A and Cámara M (2014) Evolution of the information content from the institutional perspective: El Alcázar Brewery (1928-1993) Accounting History 19(3): 369-398.

Moreno A, Jones M and Quinn M (2019) A longitudinal study of the textual characteristics in the chairman's statements of Guinness - an impression management perspective. Accounting, Auditing \& Accountability Journal. DOI: 10.1108/AAAJ-01-2018-3308.

Morys M (2014) Cycles and Depressions. In: Floud R, Humphries J and Johnson P (eds) The Cambridge Economic History of Modern Britain, Volume 2. Cambridge: Cambridge University Press, pp. 229-254.

Muzellec L and Lambkin M (2008) Corporate rebranding and the implications for brand architecture management: The case of Guinness (Diageo) Ireland. Journal of Strategic Marketing 16(4): 283-299.

Neimark M (1983) How to use content analysis in historical research. The Accounting Historians Notebook 6(2): 1-23. 
Neimark M and Tinker T (1986) The social construction of management control systems. Accounting, Organizations and Society 11(4/5): 369-395.

Noble CH, Rajiv KS and Kumar A (2002) Market orientation and alternative strategic orientations: a longitudinal assessment of performance implications. Journal of Marketing 66(4): 25-39.

North DC (1990) Institutions, Institutional Change and Economic Performance. Cambridge, UK: Cambridge University Press.

O'Gráda C (1997) Rocky road: Irish economy since independence. Manchester: Manchester University Press.

Ó hÓgartaigh C and Ó hÓgartaigh M (2004) Accounting and corporate governance archives in Ireland. Irish Accounting Review 11(1) 19-32.

Oliver C (1992) The antecedents of deinstitutionalization. Organization Studies 13(4): 563588.

ONS (2014) An examination of falling real wages. Available at: http://webarchive.nationalarchives.gov.uk/20140507230942/http://www.ons.gov.uk/on s/rel/elmr/an-examination-of-falling-real-wages/2010-to-2013/examination-of-fallingreal-wages.pdf (accessed 21 November 2017). 
Owen D (2014) The evolution of social reporting: The 'Early Days'. Social and Environmental Accountability Journal. 34(2): 75-80.

Previts GJ, Parker LD and Coffman EN (1990) An accounting historiography: Subject matter and methodology. Abacus 26(2): 136-158.

Quinn M (2014) Stability and change in management accounting over time-A century or so of evidence from Guinness. Management Accounting Research 25(1): 76-92.

Quinn M and Jackson WJ (2014) Accounting for war risk costs: management accounting change at Guinness during the First World War. Accounting History Review 24(2/3): 191-209.

Ribeiro J and Scapens R (2006) Institutional theories in management accounting change: Contributions, issues and paths for development. Qualitative Research in Accounting and Management 3(2): 94-111.

Ruane J and Todd J (2017) Changing role of the middle classes in twentieth-century Ireland. In: Biagini EF and Daly ME (eds) The Cambridge Social History of Modern Ireland. Cambridge: Cambridge University Press, pp. 177-192. 
Rowlinson M and Hassard JS (2013) Historical neo-institutionalism or neo-institutionalist history? Historical research in management and organization studies. Management and Organizational History 8(2): 111-126.

Royle E (2012) Modern Britain: A Social History 1750-2011, third edition. London: Bloomsbury Academic.

Scott WR (2014) Institutions and organizations: ideas, interests and identities. Los Angeles, CA: Sage.

Selznick P (1957) Leadership in Administration. New York: Harper \& Row.

Sharma U, Lawrence S and Lowe A (2014) Accountants as institutional entrepreneurs: changing routines in a telecommunications company. Qualitative Research in Accounting and Management 11(3): 190-214.

Spraakman G (2006) The impact of institutions on management accounting changes at the Hudson's Bay Company. Journal of Accounting and Organizational Change 2(2): $101-122$.

Spraakman G and Quinn M (2018) Accounting History research topics - An analysis of leading journals 2006 to 2015. The Accounting Historians Journal 45(1): 101-114. 
Suddaby R, Gendron Y and Lam H (2009) The organizational context of professionalism in accounting. Accounting, Organizations and Society 34(3/4): 409-427.

Tsamenyi M, Cullen J and González González JM (2006) Changes in accounting and financial information system in a Spanish electricity company: A new institutional theory analysis. Management Accounting Research 17(4): 409-432.

van der Steen M (2006) Human Agency in management accounting change. A cognitive approach to institutional theory. $\mathrm{PhD}$ thesis, University of Manchester.

Wallace WA, Rich J, Solomon I and Cherry PG (1992) Whose power prevails in disclosure practices? Auditing: A Journal of Practice and Theory 11(Supplement): 79-105.

Wanderly C, Miranda L, De Meira J and Cullen J (2011) Management accounting change: A model based on three different theoretical frameworks. Base 8(2): 111-121.

Walsh D (1987) Alcohol and Ireland. British Journal of Addition 82(2): 118-120.

Weber RP (1985) Basic content analysis. Beverly Hills, CA: Sage.

Williamson OE (2000) The new institutional economics: Taking stock, looking ahead. Journal of Economic Literature 38(3): 595-613.

Williamson OE (1985) The Economic Institutions of Capitalism. New York: Free Press. 
WHO (2018) Global status report on alcohol and health. Geneva: World Health Organisation. 


\section{Tables}

Table 1. Three pillars of institutions, based on Scott (2014)

\begin{tabular}{|l|l|l|l|}
\hline & Regulative & Normative & Cultural-cognitive \\
\hline Basis of compliance & Expedience & Social obligation & Cultural-cognitive \\
\hline Basis of order & Regulative rules & Binding expectations & Constitutive schema \\
\hline Mechanisms & Coercive & Normative & Mimetic \\
\hline Indicators & Rules, laws, sanctions & $\begin{array}{l}\text { Certification, } \\
\text { accreditation }\end{array}$ & $\begin{array}{l}\text { Common beliefs, shared } \\
\text { logics of action, } \\
\text { isomorphism }\end{array}$ \\
\hline
\end{tabular}

Table 2. Institutional stages in the period under study

\begin{tabular}{|c|c|c|}
\hline Stages & Period & Main characteristics \\
\hline $\begin{array}{l}\text { Post-war gloom } \\
\text { and doom }\end{array}$ & 1948-1959 & $\begin{array}{l}\text { - Balance of payment crisis } \\
\text { - Devaluation of the pound sterling } \\
\text { - Strict fiscal measures }\end{array}$ \\
\hline Growth & $1960-1972$ & $\begin{array}{l}\text { - Strong economic expansion } \\
\text { - Increase on social investments } \\
\text { - Improvement of the international trade }\end{array}$ \\
\hline $\begin{array}{l}\text { EEC and more } \\
\text { gloom }\end{array}$ & $1973-1984$ & $\begin{array}{l}\text { - Membership of the EEC } \\
\text { - Oil crisis } \\
\text { - Increase in unemployment and taxes in the } 1980 \mathrm{~s} \\
\text { - Recession in early } 1980 \mathrm{~s}\end{array}$ \\
\hline More growth & $1985-1996$ & $\begin{array}{l}\text { - Positive economic conditions } \\
\text { - Increase in social developments, including labour force participation } \\
\text { - Increase demand for exports }\end{array}$ \\
\hline
\end{tabular}

Table 3. Categories used for analysis

\begin{tabular}{|l|}
\hline Formal aspects \\
\hline Context \\
\hline Social aspects \\
\hline Organisational aspects \\
\hline Investments \\
\hline Results \\
\hline Future-forecast \\
\hline
\end{tabular}


Table 4. Summary of paragraphs coded

\begin{tabular}{|c|c|c|c|c|c|}
\hline \multirow{2}{*}{ Total } & \multicolumn{4}{|c|}{ Number of paragraphs labelled with X categories } & \multirow{2}{*}{ Photos/graphs } \\
\cline { 2 - 5 } & $\mathbf{X = 1}$ & $\mathbf{X = \mathbf { 2 }}$ & $\mathbf{X = 3}$ & $\mathbf{X = 4}$ & \\
\hline 1461 & $945(64.7 \%)$ & $361(24.7 \%)$ & $63(4.3 \%)$ & $5(0.3 \%)$ & $87(6 \%)$ \\
\hline
\end{tabular}

Table 5. Summary of relative importance and tendency of categories

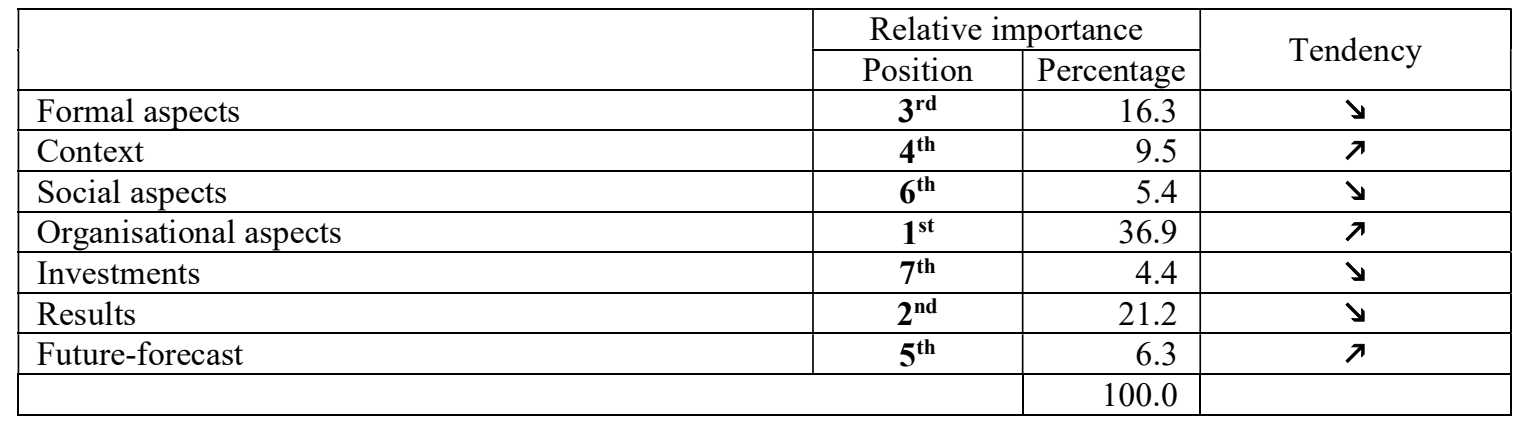

Table 6. Summary of significant differences in the categories

\begin{tabular}{|l|c|c|c|c|}
\hline & Whole period & $\begin{array}{c}1^{\text {st }}-2^{\text {nd }} \text { periods } \\
(1960 \text { transition })\end{array}$ & $\begin{array}{c}2^{\text {nd }}-3^{\text {rd }} \text { periods } \\
(1973 \text { transition })\end{array}$ & $\begin{array}{c}3^{\text {rd }}-4^{\text {th }} \text { periods } \\
(1985 \text { transition })\end{array}$ \\
\hline Formal aspects & $\mathbf{X}$ & $\mathrm{X}$ & & \\
\hline Context & & $\mathrm{X}$ & & $\mathrm{X}$ \\
\hline Social aspects & $\mathbf{X}$ & & & $\mathrm{X}$ \\
\hline Organisational aspects & & & $\mathrm{X}$ & \\
\hline Investments & $\mathbf{X}$ & & & $\mathrm{X}$ \\
\hline Results & & & & 3 \\
\hline Future-forecast & $\mathbf{X}$ & & 1 & \\
\hline Total & $\mathbf{4}$ & 2 & & \\
\hline
\end{tabular}

They represent significant differences at the 5\% level (for more details, see Appendix 3) 


\section{Appendices}

\section{Appendix 1. Extracts of 1950, 1980 and 1990 Chairman's Statements}

1950 Chairman's Statement - one of two pages

[insert file "Pages from 1950_Guinness Annual Report.jpg" here]

1980 Chairman's Statement - one of three pages

[insert file "Pages from 1980_Guinness Annual Report.jpg" here]

1990 Chairman's Statement - one of three pages

[insert file "Pages from 1990_Guinness Annual Report.jpg” here] 


\section{Appendix 2. Scheme of the issues encoded within each of the categories}

\begin{tabular}{|c|c|}
\hline Formal aspects & $\begin{array}{l}\text { Introductory aspects (usually located at the beginning of documents); submission of accounts } \\
\text { and management for approval of AGM; references that the BD is made available to shareholders; } \\
\text { thanks to workers, managers (usually for retirements) and shareholders; regrets for the deaths of } \\
\text { workers, managers and shareholders; call and agenda for AGM, BD or meetings; other formal } \\
\text { aspects. } \\
\text { Keywords: introductory aspects, submission approval, thanks, regret the death, notice of } \\
\text { meetings and agenda }\end{array}$ \\
\hline Context & $\begin{array}{l}\text { Economic, political and social context; external aspects that influence the company (e.g. } \\
\text { weather, seasonality); macroeconomic data; economic crises; political references; social } \\
\text { consumption trends; joining a trading bloc such as EEC; industry situation; competitive } \\
\text { situation; trade association(s); company's position within sector, national/international terrorism } \\
\text { and unrest } \\
\text { Keywords: crisis, stabilisation plan, economic conditions, consumer trends, EEC, sector, } \\
\text { industry, associations, competitive situation }\end{array}$ \\
\hline Soci & $\begin{array}{l}\text { Workers; social action of workers; voluntary compensation; redundancies; collective } \\
\text { agreements; performance for society and the environment; actions company carries out for } \\
\text { society, for instance, respecting alcoholism; donations; creation of a prizes/awards; } \\
\text { environmental aspects (actions such as awards or recognition that the society has with the } \\
\text { company are labelled as "Context"). } \\
\text { Keywords: staff, wages, pensions, collective agreement, society (in general), environment }\end{array}$ \\
\hline $\begin{array}{l}\text { nisational } \\
\text { ts }\end{array}$ & $\begin{array}{l}\text { Aspects related to the five traditional functions of a company: administration, provisioning, } \\
\text { production, commercial and financial. } \\
\text { Changes in the BD/management; creation and modification of departments; organisational } \\
\text { rationalisation and company structure changes; management of the company; modification of } \\
\text { Memorandum and/or Articles of Association; issues related to the BD and general management; } \\
\text { general and organisation aspects; purchase of materials; shortage of raw materials; supply } \\
\text { problems; products; diversification; aspects related to quality; production process; markets; } \\
\text { advertising actions; distribution and brand; reviews of the product by the public; increases or } \\
\text { modifications of share or debt capital; mergers; acquisitions; references to shareholders. } \\
\text { Keywords: organisation, structure, Memorandum \& Articles of Association, appointments, } \\
\text { provisioning, purchase, raw materials and supplies, products, diversification, quality, } \\
\text { customers, markets, advertising, distribution, brand, changes in capital, merger, acquisition, } \\
\text { shareholders }\end{array}$ \\
\hline Inve & $\begin{array}{l}\text { Extensions to existing capacity; new capacity; relocations; major capital works i.e. not } \\
\text { maintenance, repair or conservation (see Results); other investments, including other plant, } \\
\text { property and equipment. } \\
\text { Keywords: extension, relocation, new capacity, capital investments }\end{array}$ \\
\hline Results & $\begin{array}{l}\text { Revenue; expenses; results; depreciation; dividends; sales figur } \\
\text { Keywords: sales, income, expenses, results, depreciation, cost }\end{array}$ \\
\hline $\mathbf{F}$ & $\begin{array}{l}\text { References to the } \\
\text { (included in this } \mathrm{s}\end{array}$ \\
\hline
\end{tabular}


categories, but whose temporal horizon belongs to the future; an exception is made for issues related to "Context", which are labelled within that category, even if they refer to the future).

Keywords: future, planning, budget, plan, profit-plan 


\section{Appendix 3. Statistical analysis}

Kruskal-Wallis test by periods

\begin{tabular}{|l|r|r|r|r|r|r|r|}
\hline & \multicolumn{1}{|c|}{$\begin{array}{c}\text { Formal } \\
\text { aspects }\end{array}$} & \multicolumn{1}{c|}{ Context } & $\begin{array}{c}\text { Social } \\
\text { aspects }\end{array}$ & $\begin{array}{c}\text { Organisational } \\
\text { aspects }\end{array}$ & Investments & Results & $\begin{array}{c}\text { Future- } \\
\text { forecast }\end{array}$ \\
\hline Chi-square & 8.054 & 5.666 & 8.400 & 0.923 & 23.126 & 5.241 & 12.084 \\
\hline Df & 3 & 3 & 3 & 3 & 3 & 3 & 3 \\
\hline Asymp. sig. & $\mathbf{0 . 0 4 5}$ & 0.129 & $\mathbf{0 . 0 3 8}$ & 0.820 & $\mathbf{0 . 0 0 0}$ & 0.155 & $\mathbf{0 . 0 0 7}$ \\
\hline
\end{tabular}

Mann-Whitney test between the $1^{\text {st }}$ and the $2^{\text {nd }}$ periods (1960)

\begin{tabular}{|l|r|r|r|r|r|r|r|}
\hline & $\begin{array}{c}\text { Formal } \\
\text { aspects }\end{array}$ & Context & $\begin{array}{c}\text { Social } \\
\text { aspects }\end{array}$ & $\begin{array}{c}\text { Organis. } \\
\text { aspects }\end{array}$ & Investments & Results & $\begin{array}{c}\text { Future- } \\
\text { forecast }\end{array}$ \\
\hline Mann-Whitney U & 34.000 & 40.500 & 62.000 & 75.500 & 53.000 & 58.500 & 71.000 \\
\hline Wilcoxon W & 125.000 & 118.500 & 153.000 & 153.500 & 131.000 & 136.500 & 149.000 \\
\hline Z & -2.395 & -2.044 & -.885 & -.136 & -1.363 & -1.061 & -.383 \\
\hline Asymp. sig (2-tailed) & 0.017 & 0.041 & 0.376 & 0.892 & 0.173 & 0.289 & 0.701 \\
\hline Exact. sig. [2*(1-tailed sig.)] & $\mathbf{0 . 0 1 6}^{\mathrm{a}}$ & $\mathbf{0 . 0 4 0}^{\mathrm{a}}$ & $0.406^{\mathrm{a}}$ & $0.894^{\mathrm{a}}$ & $0.186^{\mathrm{a}}$ & $0.295^{\mathrm{a}}$ & $0.728^{\mathrm{a}}$ \\
\hline
\end{tabular}
$\mathrm{n}_{1}=12 ; \mathrm{n}_{2}=13$

Mann-Whitney test between the $2^{\text {nd }}$ and the $3^{\text {rd }}$ periods (1973)

\begin{tabular}{|l|r|r|r|r|r|r|r|}
\hline & $\begin{array}{c}\text { Formal } \\
\text { aspects }\end{array}$ & Context & $\begin{array}{c}\text { Social } \\
\text { aspects }\end{array}$ & $\begin{array}{c}\text { Organis. } \\
\text { aspects }\end{array}$ & Investments & Results & $\begin{array}{c}\text { Future- } \\
\text { forecast }\end{array}$ \\
\hline Mann-Whitney U & 67.000 & 68.000 & 63.000 & 71.000 & 25.000 & 77.000 & 66.500 \\
\hline Wilcoxon W & 158.000 & 146.000 & 141.000 & 162.000 & 103.000 & 155.000 & 157.500 \\
\hline Z & -0.598 & -0.544 & -0.825 & -0.381 & -2.889 & -0.054 & -0.626 \\
\hline Asymp. sig (2-tailed) & 0.550 & 0.586 & 0.409 & 0.703 & 0.004 & 0.957 & 0.532 \\
\hline Exact. sig. [2*(1-tailed sig.)] & $0.574^{\mathrm{a}}$ & $0.611^{\mathrm{a}}$ & $0.437^{\mathrm{a}}$ & $0.728^{\mathrm{a}}$ & $\mathbf{0 . 0 0 3}^{\mathrm{a}}$ & $0.979^{\mathrm{a}}$ & $0.538^{\mathrm{a}}$ \\
\hline
\end{tabular}
$\mathrm{n}_{2}=13 ; \mathrm{n}_{3}=12$

Mann-Whitney test between the $3^{\text {rd }}$ and the $4^{\text {th }}$ periods (1985)

\begin{tabular}{|l|r|r|r|r|r|r|r|}
\hline & $\begin{array}{c}\text { Formal } \\
\text { aspects }\end{array}$ & Context & $\begin{array}{c}\text { Social } \\
\text { aspects }\end{array}$ & $\begin{array}{c}\text { Organis. } \\
\text { aspects }\end{array}$ & Investments & Results & $\begin{array}{c}\text { Future- } \\
\text { forecast }\end{array}$ \\
\hline Mann-Whitney U & 40.000 & 50.000 & 19.000 & 69.500 & 27.000 & 43.000 & 27.500 \\
\hline Wilcoxon W & 118.000 & 128.000 & 97.000 & 147.500 & 105.000 & 121.000 & 105.500 \\
\hline Z & -1.848 & -1.276 & -3.068 & -0.144 & -2.987 & -1.676 & -2.570 \\
\hline Asymp. sig (2-tailed) & 0.065 & 0.202 & 0.002 & 0.885 & 0.003 & 0.094 & 0.010 \\
\hline Exact. sig. [2*(1-tailed sig.)] & $0.068^{\mathrm{a}}$ & $0.219^{\mathrm{a}}$ & $\mathbf{0 . 0 0 1}^{\mathrm{a}}$ & $0.887^{\mathrm{a}}$ & $\mathbf{0 . 0 0 8}^{\mathrm{a}}$ & $0.101^{\mathrm{a}}$ & $\mathbf{0 . 0 0 8}^{\mathrm{a}}$ \\
\hline
\end{tabular}

$\mathrm{n}_{3}=12 ; \mathrm{n}_{4}=12$

\section{Common note to the tables of Appendix 3:}

Bold figures represent significant differences at the $5 \%$ level. ${ }^{\text {a }}$ Not corrected for ties. 
Appendix 4. Evolution of the categories annually and by period (relative percentages)

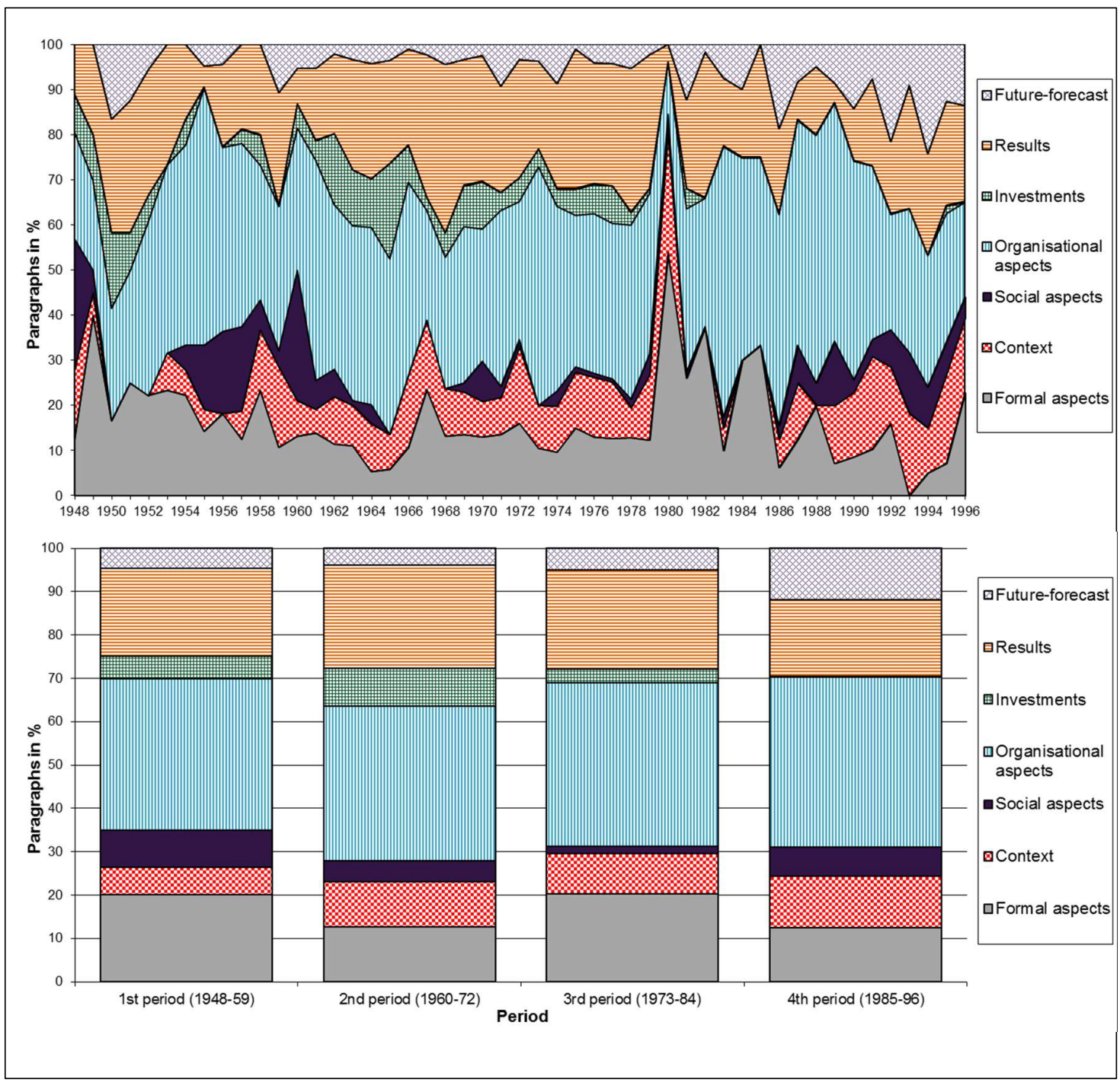

